\title{
Intravitreal bevacizumab combined with infliximab in the treatment of choroidal neovascularization secondary to age-related macular degeneration: case report series
}

\author{
Administração intravítrea de bevacizumabe combinado com infliximabe no tratamento da neovascularização \\ coroidiana secundária à degeneração macular relacionada à idade: relato de uma série de casos
}

Luiz Guilherme Azevedo de Freitas ${ }^{1,2}$, David Leonardo Cruvinel Isaac², William Thomas Tannure² ${ }^{2}$, Luís Alexandre Rassi Gabriel², Ricardo Gomes dos Reis², Alan Ricardo Rassi², Clovis Arcoverde de Freitas ${ }^{3}$, Marcos Pereira de Ávila ${ }^{2,3}$

\begin{abstract}
Purpose: To evaluate the feasibility of the combined use of bevacizumab (Avastin ${ }^{\circledR}$ ) and combined with infliximab (Remicade ${ }^{\circledR}$ ) in the treatment of naive choroidal neovascularization due to age-related macular degeneration eyes.

Methods: Intravitreal injections of bevacizumab combined with infliximab in 6 neovascular age-related macular degeneration eyes. All patients underwent complete ophthalmologic examination on the initial visit and at days 1, 30, 60, $90,120,150$ and 180 following the first injection. Optical coherence tomography and fluorescein angiography were performed during at initial visit and monthly during the 6 months follow-up period. Electroretinography was performed before and 30 days after initial injection, in order to evaluate retinal toxicity induced by such treatment.

Results: Thirty days after the first injection, 5 eyes (83\%) shown decrease in macular thickness. No change was seen in electroretinogram in any eyes compared to initially performed electroretinogram. All phakic eyes developed cataract. One patient developed vitritis and was submitted to medical treatment successfully. At the end of the 6 months follow-up period, 4 patients showed significant improvement in the exudative process of choroidal neovascularization. One eye had mild persistent submacular fluid without active choroidal neovascularization, and another eye had persistent amount of intraretinal fluid due to active choroidal neovascularization.

Conclusion: The combined use of bevacizumab with infliximab in eyes with neovascular age-related macular degeneration was effective in reducing leakage and improving the macular thickness. However, it is not possible to assert that the results were related to synergic effects of the combination therapy. A controlled study with more cases is necessary to precisely define the complication rates; however the dosage and/or association of drugs studied in this research should not be recommended in clinical practice due to cataract as well as inflammatory reaction.
\end{abstract}

Keywords: Retina; Macular degeneration/complications; Choroidal neovascularization/etiology; Intravitreal injections; Optical coherence tomography; Angiogenesis inhibitors/therapeutic use

\section{RESUMO}

Objetivo: Avaliar a viabilidade do uso combinado do bevacizumabe (Avastin ${ }^{\circledR}$ ) e do infliximabe (Remicade ${ }^{\circledast}$ ) no tratamento da degeneração macular relacionada à idade neovascular em pacientes sem tratamentos prévio.

Métodos: Foram realizadas injeções intravítreas de bevacizumabe combinado com infliximabe em 6 pacientes portadores de degeneração macular relacionada à idade neovascular. Todos foram submetidos ao exame oftalmológico completo, no primeiro dia de consulta, no dia seguinte a cada injeção e mensalmente até completar seis meses após a primeira injeção. Foram realizados tomografia de coerência óptica e angiografia fluoresceínica na primeira consulta e mensalmente, até completar 6 meses após o primeiro procedimento. Eletrorretinografia também foi realizada antes da injeção e 30 dias após, no intuito de avaliar toxidade retiniana.

Resultados: Ao final de 30 dias da primeira injeção, 5 (83\%) pacientes apresentaram diminuição na espessura macular. Não foi visualizada alteração à eletrorretinografia em relação ao exame inicial em 100\% os pacientes. Cinco pacientes (100\% dos fácicos) desenvolveram catarata. Um paciente desenvolveu vitreíte e foi tratado com sucesso. Ao final dos 6 meses, 4 pacientes apresentaram melhora significativa da neovascularização de coroide, porém ainda com foco de neovascularização em atividade, um paciente apresentava discreta persistência de fluido submacular sem neovascularização ativa e 1 paciente persistia importante quantidade de fluido intrarretiniano com neovascularização em atividade.

Discussão: Avaliou-se o uso combinado do bevacizumabe com infliximabe em pacientes portadores de degeneração macular relacionada à idade neovascular e a associação mostrou-se eficaz na redução do vazamento da neovascularização de coroide e da espessura macular ao tomografia de coerência óptica. Não é possivel, no entanto, afirmar se os resultados apresentam efeitos sinérgicos pela associação entre as duas drogas. Um estudo com maior número de casos énecessário para definir exatamente as taxas de catarata e vitreíte da associação entre as drogas, no entanto, ao menos na dosagem estudada no presente trabalho, a associação não deveria ser recomendada na prática clínica.

Descritores: Retina; Degeneração macular/complications; Neovascularização rețniana/etiologia; Injeções intravítreas; Tomografia de coerência óptica, Inibidores da angiogênese/uso terapêutico

\footnotetext{
Submitted for publication: October 17,2012

Accepted for publication: March 20, 2013

Study conducted at the Centro de Referência em Oftalmologia, Hospital das Clínicas UFG (CEROF/ $\mathrm{HC} / \mathrm{FM} / \mathrm{UFG}$ ).

Physician, Hospital de Olhos Santa Luzia, Recife (PE), Brazil.

Physician, Department of Ophthalmology, Universidade Federal de Goiás, Goiânia (GO), Brazil.

${ }^{3}$ Physician, Centro Brasileiro da Visão - CBV, Brasília (DF), Brazil.
}

Funding: No specific financial support was available for this study.

Disclosure of potential conflicts of interest: L.G.A.de Freitas, None; D.L.C.Isaac, None; W.T.Tanure, None; L.A.R.Gabriel, None; R.G.dos Reis, None; A.R.Rassi, None; C.A.de Freitas, None; M.P.de Ávila, None.

Correspondence address: Luiz Guilherme Azevedo de Freitas. Hospital de Olhos Santa Luzia. Estrada do Encanamento, 909 - Recife (PE), Brazil - 52070-000 - E-mail: luizgfreitas@gmail.com 


\section{INTRODUCTION}

Age-related macular degeneration (ARMD) is the leading cause of central vision loss in individuals over 60 years of age. In the United States, it is related to $54.4 \%$ of visual impairment cases and $22.9 \%$ of legal blindness in Caucasian population ${ }^{(1,2)}$. The neovascular form of ARMD has more aggressive and devastating effect, accounting for $80 \%$ of the cases of legal blindness by the disease ${ }^{(3)}$.

The treatment for neovascular ARMD with drugs inhibiting vascular endothelial growth factor (VEGF) such as ranibizumab and bevacizumab are currently the most widely used ${ }^{(4,5)}$. The efficacy and safety of the use of ranibizumab was proven in studies such as MARINA and ANCHOR, which determined the benefit of using monthly injections of the drug. In both studies patients showed significant visual gain after 3 applications of medication ${ }^{(4,5)}$.

Other studies such as PIER and PRONTO assessed alternative schedules for the use of ranibizumab involving fewer injections. Both studies showed the benefit of using ranibizumab but with results for visual acuity slightly worse than the MARINA and ANCHOR studies(6,7).

Whether ranibizumab or bevacizumab, a factor of this therapeutic modality is the necessity for multiple injections to maintain the visual benefit achieved in the first applications.

A recent study compared the efficacy and safety of bevacizumab with ranibizumab for the treatment of neovascular age-related macular degeneration. It was noted that both showed equivalent results with regard to visual acuity when administered monthly or as needed, for a year ${ }^{(8)}$.

The limitation of this therapeutic modality is the need for multiple injections to maintain the visual benefit achieved in the first applications.

One way to try to extend the anatomic and visual benefits would be to try to block another agent of the angiogenic pathway. An important molecule in the formation of neovascularization is the tumor necrosis factor (TNF). It is released in the early stages of the disease and participates in the cyclic inflammatory process in the formation of choroidal neovascularization (CNV) $)^{(9)}$.

The blockage of TNF expression can be achieved through the use of monoclonal chimeric antibodies such as infliximab. This drug is used in the treatment of rheumatoid arthritis, spondyloarthropathies and Crohn's disease. Intravenous infusion of the drug in the treatment of arthritis patients who also carried the neovascular form of ARMD, led to improvement in visual acuity and regression of the CNV. Neither ocular nor extraocular effects were observed in these patients ${ }^{(10)}$.

Giganti et al., in a pilot study evaluating the safety of intravitreal infliximab in rabbits, showed no electrophysiological or histological damage in dosage up to $1.7 \mathrm{mg}{ }^{(11)}$. Theodossiadis et al., also demonstrated the safety of intravitreal infliximab in New Zealand white rabbits, which received intravitreal injections of up to $2 \mathrm{mg}$ of infliximab, and Rassi et al., demonstrated safety in the use of $2 \mathrm{mg}$ of 2 to 3 serial applications in rabbits of the same breed ${ }^{(12,13)}$.

The intravitreal use of infliximab in humans was first reported in 2009, when three selected eyes with active CNV previously and unsuccessfully treated with bevacizumab received intravitreous injections of $0.05 \mathrm{ml}$ of infliximab in each eye and resulted in improvement in best-corrected visual acuity (BCVA) as well as the resolution of central macular thickness ${ }^{(14)}$.

The purpose of this study is to evaluate the feasibility of the combined use of bevacizumab (Avastin ${ }^{\circledR}$, Roche, Brazil) and infliximab (Remicade ${ }^{\circledR}$, Schering-Plough, United States) in the treatment of neovascular ARMD.

\section{METHODS}

The study was approved by the Ethics Committee of Federal University of Goias. It was conducted a prospective, interventional treatment study in the period from March to October 2011, where patients with neovascular ARMD were selected.
Inclusion criteria: Eyes with CNV secondary to ARMD diagnosed by means of fluorescein angiography (FA) (Topcon TRC 50DX ${ }^{\circledR}$, Topcon, Japan) and by optical coherence tomography (Stratus - OCT ${ }^{\circledR}$, Carl Zeiss Meditec Inc, USA); central macular thickness $\geq 300 \mu \mathrm{m}$ by Thickness Map Report on $\mathrm{OCT}^{\circledR}$; only one eye in each patient could be enrolled in the study; eyes should not be previously treated with antiangiogenic drugs; and the patient should provide a signed consent form.

Exclusion criteria: Eyes with cataracts or corneal opacities that precluded adequate visualization of the retina; cataract surgery performed less than three months before the possible intravitreal injection; eyes with retinal diseases other than ARMD; vitreoretinal surgery or previous treatment for neovascular AMD at any time; and refusal by the patient to participate in the study.

All intravitreal injections were performed by the same surgeon, with 30-gauge needle positioned at $3.5 \mathrm{~mm}$ from the limbus. Two separate injections were made with measurements at 2 different sites. After the injections, anterior chamber paracentesis was performed.

Infliximab (Remicade ${ }^{\circledR}$, Schering-Plough, United States) is available in a bottle containing 100 mg. Its aliquotation was performed in a sterile environment (Laminar Flow AHC-2D1, ESCO, USA) using Eppendorf vials containing $2 \mathrm{mg}$ of infliximab. After aliquotation, the vials were kept under refrigeration at $2-8^{\circ} \mathrm{C}$.

Patients enrolled in the study underwent a complete ophthalmologic examination, on the first day of medical appointment, the day after each injection and monthly until completion of six months from the first injection.

The FA and optical coherence tomography (OCT) examinations were performed at the first visit and then monthly until completion of the six months after the first procedure. Full field electroretinography (ERG) examinations were performed in all patients before the injection and 30 days after each injection in order to evaluate the possibility of retinal toxicity. To classify the lens status, the LOCS III(15) classification system was used.

\section{RESULTS}

Six eyes ( 6 patients) treated with combined bevacizumab and infliximab were evaluated. Regarding gender, 5 patients (83\%) were female and all of them aged over 70 years.

On biomicroscopic examination, one patient was pseudophakic and five patients had NO3 NC3 cataract.

Two consecutive injections were performed in 5 patients and 3 injections in 1 patient in the follow-up period of 6 months.

Thirty days after the first injection, 5 (83\%) patients showed decrease in macular thickness. In one patient a significant presence of macular fluid was present, but the FA has shown less leakage in late phases when compared to the pre-injection (Figures 1 and 2).

Thirty days after each injection, no patient had abnormal electroretinogram findings compared to initial examination.

Two months after the first injection, two eyes developed NO4 NC4 cataract and 3 eyes developed NO5 NC5 cataract, these last, it was necessary to perform phacoemulsification with implantation of intraocular lens for better retinal visualization and performance of FA and OCT exams (Table 1).

Anterior chamber cells were observed in 3 patients (50\%) in the first days after each injection. One patient showed vitritis and vasculitis 1 month after the second application. Treatment was conducted, showing improvement of the retinal vascular process after 30 days (Figure 3). Treatment was performed with prednisolone eye drops 6/6h for 15 days. After 6 months, 4 eyes showed significant improvement of CNV fluid and retinal edema. However focusing on active CNV, one eye had mild persistent submacular fluid without active CNV, and another eye had persistent amount of intraretinal fluid due to active CNV.

The intraocular pressure remained within normal limits during the study (Table 1). 

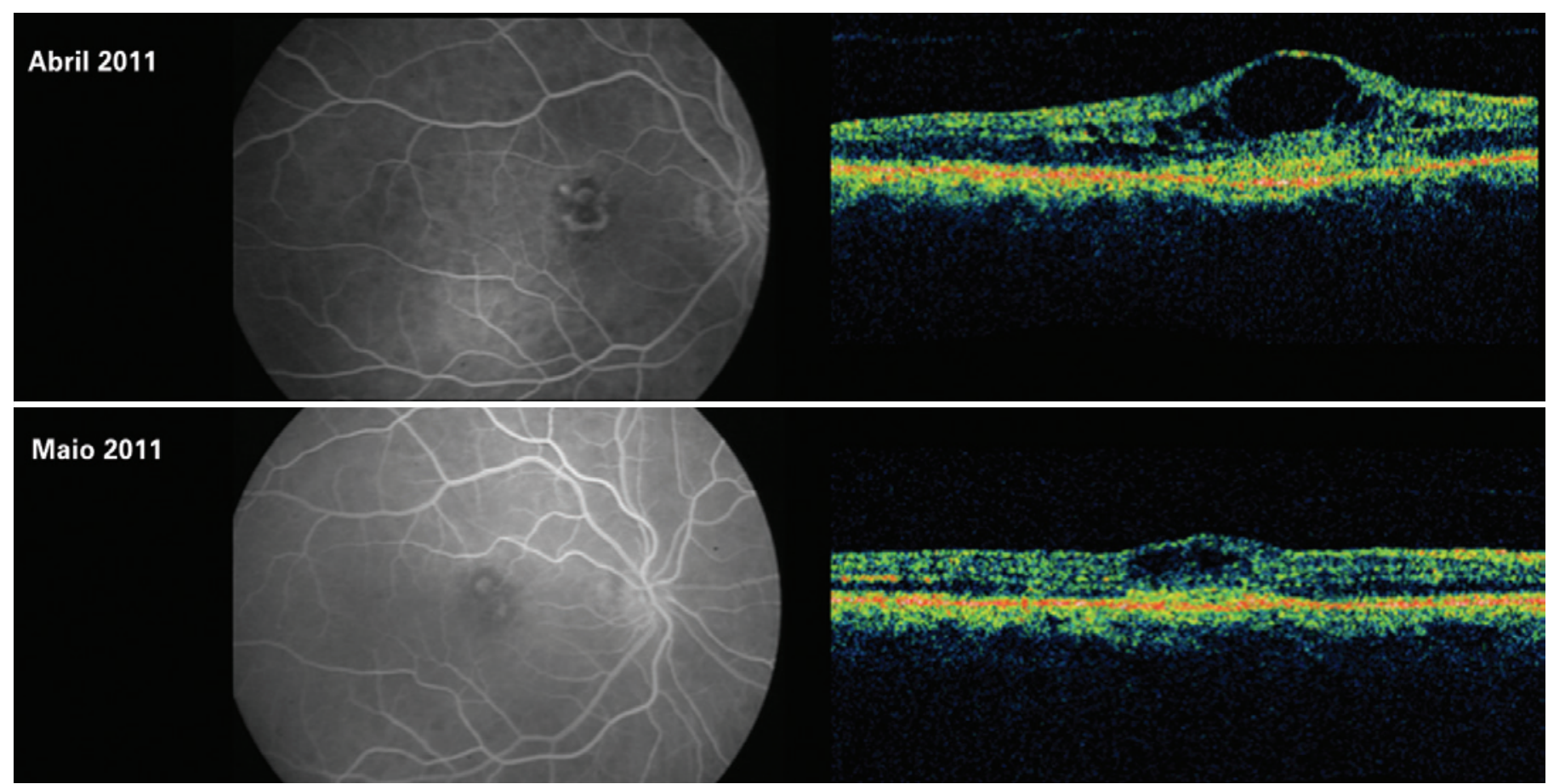

Figure 1. In this patient can notice significant reduction of macular thickness by the OCT and in the fluorescein angiography show less leakage in late phases when compared to the pre-injection phase.

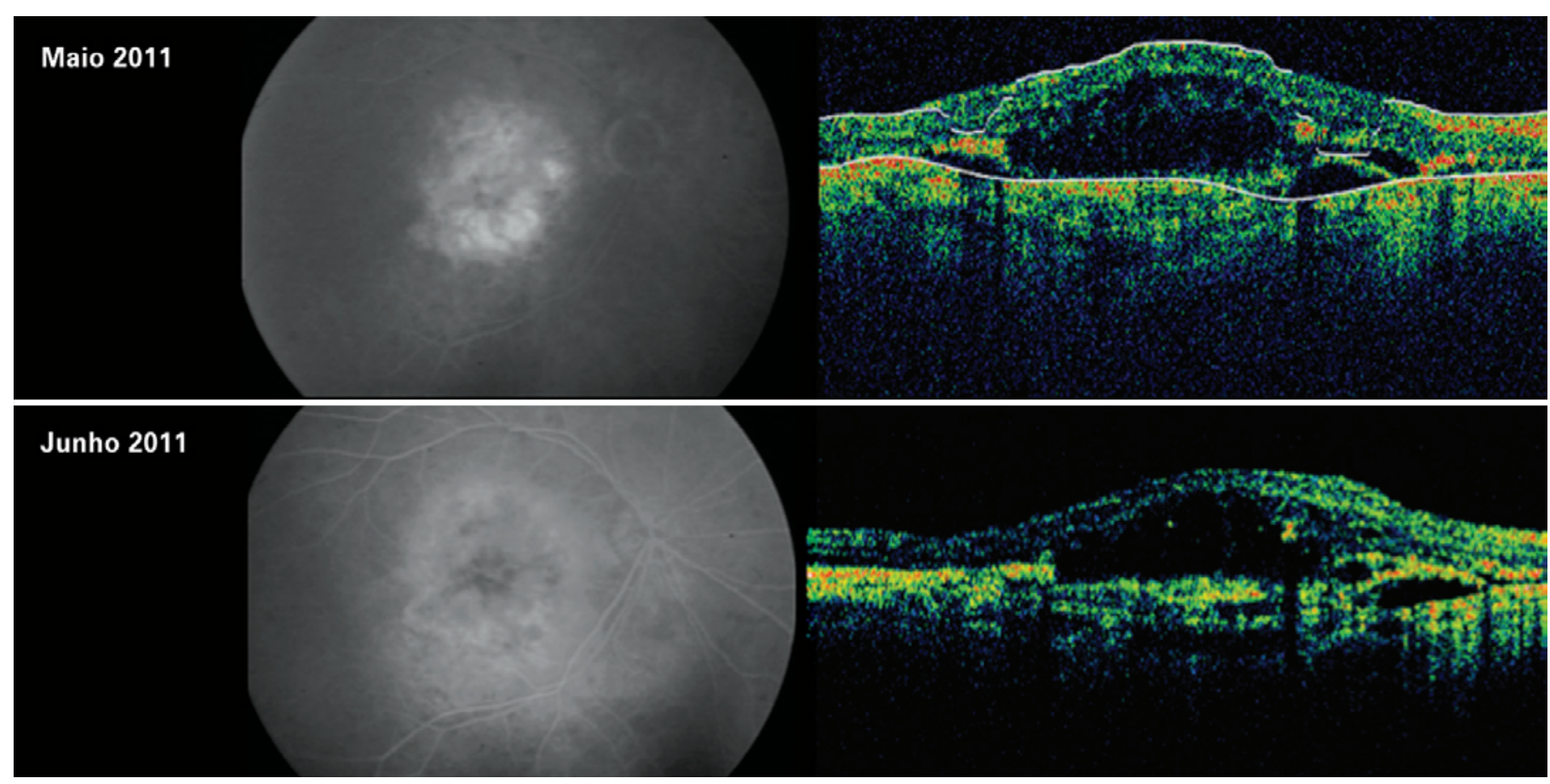

Figure 2. Significant persistence of fluid in the macula 30 days after first injection. But can notice less leakage in late phases when compared to the pre-injection.

\section{DISCUSSION}

There are many advances in the treatment for neovascular ARMD involving monoclonal antibodies. The results of treatments using anti-VEGF drugs have been proven through various studies, although, therapies with drugs that inhibit TNF are still being investigated ${ }^{(16)}$.
The tumor necrosis factor is a very active pro-inflammatory cytokine and can stimulate specific and nonspecific immune systems. It activates $B$ and $T$ lymphocytes, and macrophages, increases the levels of pro-inflammatory cytokines such as interleukin 1, 6 and 8 (IL-1, IL-6 and IL-8), increases the attraction of neutrophils to the inflammatory 
Table 1. Clinical eye exams before and after injections

\begin{tabular}{|c|c|c|c|c|c|c|c|c|}
\hline & $\begin{array}{c}\text { BCVA } \\
\text { Before } \\
\text { treatment }\end{array}$ & $\begin{array}{c}\text { BCVA } \\
30 \text { days after } \\
\text { first injection }\end{array}$ & $\begin{array}{c}\text { BCVA } \\
90 \text { days after } \\
\text { first injection }\end{array}$ & $\begin{array}{c}\text { IOP } \\
\text { Before } \\
\text { treatment }\end{array}$ & $\begin{array}{c}\text { IOP } \\
90 \text { days after } \\
\text { first injection }\end{array}$ & $\begin{array}{c}\text { Anterior chamber } \\
\text { inflammatory reaction } \\
\text { by biomicroscopy }\end{array}$ & $\begin{array}{l}\text { Cataract } \\
\text { Before } \\
\text { treatment }\end{array}$ & $\begin{array}{c}\text { Cataract } \\
2 \text { months after } \\
\text { first injection }\end{array}$ \\
\hline Eye 1 & 0,2 & 0,4 & 0,5 & 16 & 14 & + & $\mathrm{NO} 4$ & NC4 \\
\hline Eye 2 & HM & CF $3^{\prime}$ & CF $3^{\prime}$ & 14 & 13 & - & $\mathrm{NO} 4$ & NC4 \\
\hline Eye 3 & 0,1 & 0,1 & 0,15 & 14 & 18 & + & NO5 & NC5 \\
\hline Eye 4 & CF $4^{\prime}$ & CF $4^{\prime}$ & CF $4^{\prime}$ & 14 & 12 & - & NO5 & NC5 \\
\hline Eye 5 & CF $7^{\prime}$ & CF $7^{\prime}$ & CF $1^{\prime}$ & 12 & 13 & - & NO5 & NC5 \\
\hline Eye 6 & CF $4^{\prime}$ & CF $4^{\prime}$ & CF $4^{\prime}$ & 13 & 12 & + & Pseudophakic & Pseudophakic \\
\hline
\end{tabular}

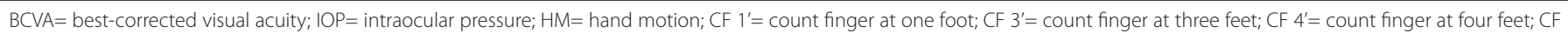
$7^{\prime}=$ count finger at seven feet.
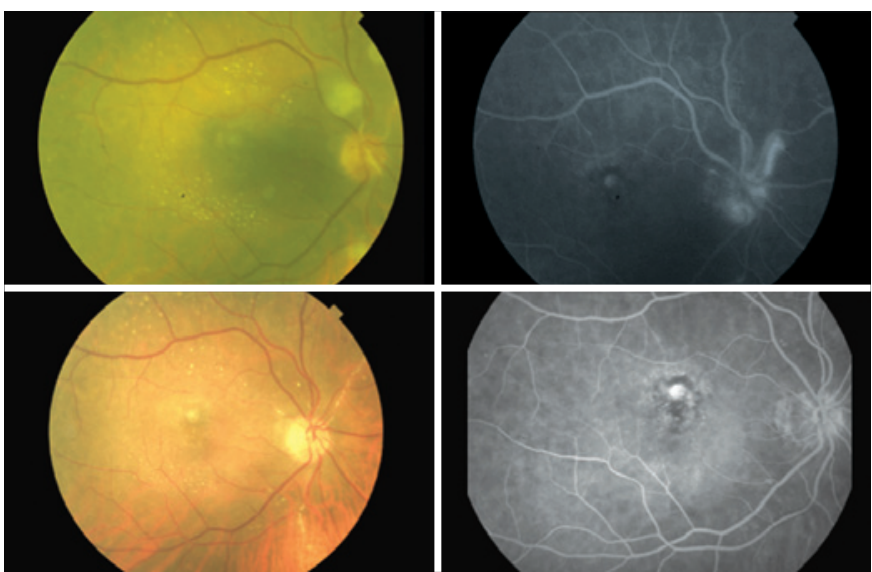

Figure 3: A patient who showed vitritis and vasculitis 30 days after the second injection (figure above). After 30 days of treatment showing improvement of the retinal vascular process (figure below).

site when it stimulates the synthesis of adhesion molecules and the activation of neutrophils ${ }^{(16,17)}$. Oh et al., in 1999, investigated the distribution of inflammatory mediators such as IL-1, TNF and angiogenic cytokines and as well as vascular endothelial growth factor (VEGF), in the choroidal neovascularization process. Results showed that IL-1 and TNF alpha, secreted by macrophages can promote at least in part, angiogenesis in CNV by stimulating the production of VEGF by retinal pigment epithelium (RPE) cells ${ }^{(18)}$.

Studies have shown that TNF alpha plays an active role in the pathogenesis of inflammatory eye diseases and neurodegenerative eye diseases, macular edema, retinal neovascularization and proliferative vitreoretinopathy (PVR). Intravitreal injection of TNF alpha in mice causes inflammation and abnormal permeability in inner blood-retinal barrier, manifesting an inflammatory process, as well as increased levels of this cytokine in the eye $\mathrm{e}^{(19-22)}$

The blockage of TNF can be obtained by use of chimeric monoclonal antibodies such as infliximab. This drug has been used to treat rheumatoid arthritis, spondyloarthropathies and Crohn's disease. Intravenous infusion of this drug in the treatment of arthritis patients who also carried the neovascular form of ARMD, led to improvement in visual acuity and regression of choroidal membrane. No adverse ocular or extraocular effect was presented in these patients ${ }^{(10,13)}$.

The safety of intravitreal infliximab has been demonstrated by studies in experimental animal models indicating that it can be safely administered at a dose of $2 \mathrm{mg}$. In these studies electrophysiological tests were performed which showed normal results in all rabbit eyes that were injected with 1 or $2 \mathrm{mg}$ infliximab ${ }^{(14)}$. In this current study, we selected the dose of $2 \mathrm{mg}$ of infliximab to be injected into the vitreous cavity of these eyes.

Electrophysiology was performed before injection and at 30 and 60 days. All results were normal. For these findings it is supposed that this association may be non-toxic to the human retina controlled. Studies with more patients should be performed to improve the reliability of results.

Arias et al., reported the use of intra-vitreous infliximab (2 mg/ $0.05 \mathrm{ml}$ ) in patients with neovascular ARMD does not respond to serial injections of bevacizumab and ranibizumab. In this series of cases, reaction was observed in the anterior chamber and vitritis in $50 \%{ }^{(23)}$. In this study, three patients had anterior chamber reaction $(1+)$ with flare and cells in the first postoperative day.

Some authors in 2011 evaluated the use of infliximab in rabbits ( $2 \mathrm{mg}$ ). In the study, the presence of few lymphocytes in the retina of two rabbits was seen and had an important inflammatory membrane on the surface of the vitreous and retinal posterior cortex. Despite inflammatory findings, the electroretinogram study in the rabbits was normal, as in this current study ${ }^{(13)}$.

Thus, despite the findings of inflammation in the eyes treated with infliximab, it did not alter the electroretinography (ERG) suggesting no specific toxicity to the retina and its operation.

In one patient uveitis and retinal vasculitis was detected, during a visit of 30 days. The patient was treated with steroids. After 15 days of treatment, the patient had regression of angiographic signs of vasculitis.

Inflammatory reactions were also observed by Wu and colleagues in 8 patients with diabetic macular edema ( $20 \%$ of total patients) who underwent intravitreal injection of infliximab $(2 \mathrm{mg})^{(24)}$ similar to 4 cases reported by Giganti and colleagues who injected infliximab $(0.5 \mathrm{mg})$ in 2 patients with macular edema and 2 patients with neovascular ARMD where $100 \%$ of the patients showed uveitis ${ }^{(25)}$.

Both infliximab and bevacizumab are monoclonal humanized antibodies. Bevacizumab is comprised of $5 \%$ murine to $95 \%$ human framework while infliximab is $25 \%$ murine and $75 \%$ human framework.

One might suppose that the greater presence of murine components in infliximab would be an important factor for the greatest potential to generate vitritis in treated eyes, in the current series. Other anti-TNF drugs such as adalimumab are 100\% humanized and is believed that it might have have fewer inflammatory components than infliximab.

Other adverse effect was observed. All phakic eyes (5 patients) had progression of cataracts in the two months following the injection and in 3 additional eyes (50\% of patients) the phacoemulsification was necessary in order to provide the possibility of fundus evaluation.

In none of the animal studies and case series in humans the progression of cataract was demonstrated ${ }^{(13,23)}$. As in studies with 
INTRAVITREAL BEVACIZUMAB COMBINED WITH INFLIXIMAB IN THE TREATMENT OF CHOROIDAL NEOVASCULARIZATION SECONDARY TO AGE-RELATED MACULAR DEGENERATION: CASE REPORT SERIES

anti-VEGF (MARINA, ANCHOR and CATT) there is no cataract progression. It could be presumed that the association between infliximab and bevacizumab could accelerate cataract progression.

\section{CONCLUSION}

The combination was effective in reducing the leakage of CNV and macular thickness in OCT. However, it is not possible to assert that the results are due to synergic effects of both drugs combination. Despite the small number of patients and not evidence of functional changes by the ERG, the findings of vitritis and the progression of cataracts in eyes submitted to this treatment were evident.

A controlled study with more number of eyes is necessary to precisely define the rates of cataract and vitritis development as well as therapeutical effect of the bevacizumab/infliximab association; however, due to the clinical findings observed, the dosage analysed in this study and, should not be recommended in clinical practice. By an unknown; however this hypotheses should be evaluated by futures studies designed for this purpose.

\section{REFERENCES}

1. Congdon N, O'Colmain B, Klaver CC, Klein R, Muñoz B, Friedman DS, Kempen J, Taylor HR, Mitchell P; Eye Diseases Prevalence Research Group. Causes and prevalence of visual impairment among adults in the United States. Arch Ophthalmol. 2004; 122(4):477-85

2. Rein DB, Wittenborn JS, Zhang $X$, Honeycutt AA, Lesesne SB, Saaddine J; Vision Health Cost-Effectiveness Study Group. Forecasting age-related macular degeneration through the year 2050: the potential impact of new treatments. Arch Ophthalmol. 2009:127(4):533-40. Comment in: JAMA. 2009:301(20):2152-3.

3. Chandra SR, Gragoudas ES, Friedman E, Van Buskirk EM, Klein ML. Natural history of disciform degeneration of the macula. Am J Ophthalmol. 1974;78(4):579-82.

4. Rosenfeld PJ, Brown DM, Heier JS, Boyer DS, Kaiser PK, Chung CY, Kim RY; MARINA Study Group. Ranibizumab for neovascular age-related macular degeneration. N Engl J Med. 2006:355(14):1419-31. Comment in: N Engl J Med. 2006; 355(14):1493-5. N Engl J Med. 2006;355(14):1409-12. N Eng J Med. 2007;356(7):748-9; author reply 749-50. N Engl J Med. 2007;356(7):747-8; author reply 749-50.

5. Brown G. Comparative effectiveness. Curr Opin Ophthalmol. 2008;19(3):175-6.

6. Abraham P, Yue H, Wilson L. Randomized, double-masked, sham-controlled trial of ranibizumab for neovascular age-related macular degeneration: PIER study year 2 . Am J Ophthalmol. 2010;150(3):315-24.e1.

7. Lalwani GA, Rosenfeld PJ, Fung AE, Dubovy SR, Michels S, Feuer W, et al. A variabledosing regimen with intravitreal ranibizumab for neovascular age-related macular degeneration: year 2 of the PrONTO Study. Am J Ophthalmol. 2009;148(1):43-58.e1. Comment in: Am J Ophthalmol. 2009; 148(1):1-3.

8. CATT Research Group, Martin DF, Maguire MG, Ying GS, Grunwald JE, Fine SL, Jaffe GJ. Ranibizumab and bevacizumab for neovascular age-related macular degeneration. N Engl J Med. 2011;364(20):1897-908. Comment in: Clin Experiment Ophthalmol.
2011;39(7):718-20. N Engl J Med. 2011;365(23):2238; N Engl J Med. 2011;365(23):2237; author reply 2237. N Engl J Med. 2011:364(20):1966-7.

9. Lima Filho AA, Dantas AM, Sallum JM, Ferreira Filho N, Marback RL, Org. Bases da Oftalmologia. Rio de Janeiro: Cultura Médica; 2008. v. 1. p.429-38.

10. Markomichelakis NN, Theodossiadis PG, Sfikakis PP. Regression of neovascular agerelated macular degeneration following infliximab therapy. Am J Ophthalmol. 2005; 139(3):537-40.

11. Giganti M, Beer PM, Lemanski N, Hartman C, Schartman J, Falk N. Adverse events after intravitreal infliximab (Remicade). Retina. 2010;30(1):71-80.

12. Theodossiadis PG, Liarakos VS, Sfikakis PP, Charonis A, Agrogiannis G, Kavantzas N, et al. Intravitreal administration of the anti-TNF monoclonal antibody infliximab in the rabbit. Graefes Arch Clin Exp Ophthalmol, 2009; 247(2):273-81.

13. Rassi AR, Rigueiro MP, Isaac DL, Dourado L, Abud MB, Freitas EC, et al. [A safety study of retinal toxicity after serial intravitreal injections of infliximab in rabbits eyes]. Arq Bras Oftalmol. 2011t;74(5):352-6. Portuguese.

14. Theodossiadis PG, Liarakos VS, Sfikakis PP, Vergados IA, Theodossiadis GP. Intravitrea administration of the anti-tumor necrosis factor agent infliximab for neovascular age-related macular degeneration. Am J Ophthalmol. 2009;147(5):825-30, 830.e1.

15. Magalhães FP, Costa EF, Cariello AJ, Rodrigues EB, Hofling-Lima AL. Comparative analysis of the nuclear lens opalescence by the Lens Opacities Classification System III with nuclear density values provided by Oculus Pentacam: a cross-section study using Pentacam Nucleus Staging software. Arq Bras Oftalmol. 2011;74(2):110-3.

16. Rodrigues EB, Farah ME, Maia M, Penha FM, Regatieri C, Melo GB, et al. Therapeutic monoclonal antibodies in ophthalmology. Prog Retin Eye Res. 2009;28(2):117-44.

17. Marcelo LG, Thelma LS. Principais imunomoduladores. In: Marcelo LG, Thelma LS Reumato-oftalmologia. São Paulo: Tecmedd; 2007. Cap. 6. p.94-102.

18. Oh H, Takagi H, Takagi C, Suzuma K, Otani A, Ishida K, et al. The potential angiogenic role of macrophages in the formation of choroidal neovascular membranes. Invest Ophthalmol Vis Sci [Internet]. 1999[cited 2011 Dec 21];40(9):1891-8. Available from: http://www.iovs.org/content/40/9/1891.long

19. De Vos AF, Klaren VN, Kijlstra A. Expression of multiple cytokines and IL-1RA in the uvea and retina during endotoxin-induced uveitis in the rat. Invest Ophthalmol Vis Sci[Internet]. 1994[cited 2011 Nov 24];35(11):3873-83. Available from: http://www. iovs.org/content/35/11/3873.long

20. Derevjanik NL, Vinores SA, Xiao WH, Mori K, Turon T, Hudish, T, et al. Quantitative assessment of the integrity of the blood-retinal barrier in mice. Invest Ophthalmol Vis Sci [Internet]. 2002[cited 2012 Sep 15]43(7):2462-7. Available from: http://www. iovs.org/content/43/7/2462.long

21. Limb GA, Hollifield RD, Webste, L, Charteris DG, Chignell AH. Soluble TNF receptors in vitreoretinal proliferative disease. Invest Ophthalmol Vis Sci [Internet]. 2001[cited 2011 Jun 21];42(7):1586-91. Available from: http://www.iovs.org/content/42/7/1586.long

22. Theodossiadis PG, Markomichelaki, NN, Sfikakis PP. Tumor necrosis factor antagonists: preliminary evidence for an emerging approach in the treatment of ocular inflammation. Retina. 2007;27(4):399-413.

23. Arias L, Caminal JM, Badia MB, Rubio MJ, Catala J, Pujol O. Intravitreal infliximab in patients with macular degeneration who are nonresponders to antivascular endothelial growth factor therapy. Retina. 2010;30(10):1601-8.

24. Wu L, Hernandez-Bogantes E, Roca JA, Arevalo JF, Barraza K, Lasave AF. intravitreal tumor necrosis factor inhibitors in the treatment of refractory diabetic macular edema: a pilot study from the Pan-American Collaborative Retina Study Group. Retina. 2011; 31(2):298-303.Comment in: Retina. 2012;32(10):2179; author reply 2179-80.

25. Giganti M, Beer PM, Lemanski N, Hartman C, Schartman J, Falk N. Adverse events after intravitreal infliximab (Remicade). Retina. 2010;30(1):71-80. 